Institute of $\mathbf{F}_{\text {ood and }} \mathbf{A}$ gricultural $\mathbf{S}_{\text {ciences }}$

\title{
Scentless Plant Bugs, Jadera sp. (Insecta: Hemiptera: Rhopalidae) ${ }^{1}$
}

\author{
F. W. Mead and T. R. Fasulo ${ }^{2}$
}

\section{Introduction}

Two species of Jadera are known from Florida, J. antica Walker and J. haematoloma

(Herrich-Schaeffer), but only the latter species is common. When J. haematoloma appears in large colonies in yards and gardens, people become curious and/or alarmed and contact agricultural officials for information. Mothers often become upset over their children's clothes being stained red from the squashed bodies of J. haematoloma, due to their children playing on infested lawns. The bugs aggregate to feed on seeds that have dropped to the ground from trees overhead, especially from goldenrain trees, Koelreuteria spp., (Sapindaceae). Wheeler (1982) documented J. haematoloma as a nuisance insect in Texas, and having invaded homes from nearby Chinaberry trees in Oklahoma. Jadera bugs are often confused with the boxelder bug, Boisea trivittatus (Say), but they are different species in the same insect family. Boxelder bugs also cause concern when they appear in great numbers at the end of summer or early fall in states to the north and west of Florida.

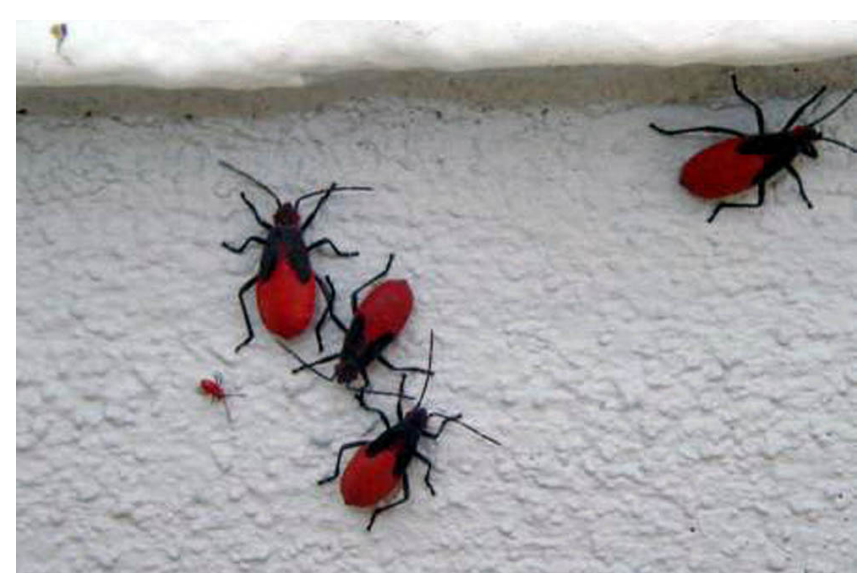

Figure 1. Nymphs of the Jadera bug, Jadera haematoloma (Herrich-Schaeffer), on the side of a house. Credits: Robert E. Wilt, Jr.

\section{Synonymy}

Jadera haematoloma was described previously in the genus Leptocoris and has been recorded in Serinetha, Lygaeus, and Pyrrhotes. Jadera antica (Walker) is the name currently accepted for Jadera sanguinolenta (Fabricius) of various authors having reported it in southern Florida and southward. The true sanguinolenta is a Neotropical species that

1. This document is EENY-130 (originally published as DPI Entomology Circular 277), one of a series of Featured Creatures from the Entomology and Nematology Department, Florida Cooperative Extension Service, Institute of Food and Agricultural Sciences, University of Florida. Published: May 2000. This document is also available on Featured Creatures Website at http://creatures.ifas.ufl.edu. Please visit the EDIS Website at http://edis.ifas.ufl.edu. Additional information on these organisms, including many color photographs, is available at the Entomology and Nematology Department website at http://entnemdept.ifas.ufl.edu/ and the Division of Plant Industry website at http://www.doacs.state.fl.us/ pi/.

2. F. W. Mead, Florida Department of Agriculture and Consumer Services, Division of Plant Industry, Gainesville, FL and T. R. Fasulo, Entomology and Nematology Department, University of Florida, Gainesville, FL.

The Institute of Food and Agricultural Sciences is an equal opportunity/affirmative action employer authorized to provide research, educational information and other services only to individuals and institutions that function without regard to race, color, sex, age, handicap, or national origin. For information on obtaining other extension publications, contact your county Cooperative Extension Service office. Florida Cooperative Extension Service/Institute of Food and Agricultural Sciences/University of Florida/Christine Taylor Waddill, Dean. 
occurs in Puerto Rico and the Virgin Islands, but not in the continental U.S.A.

\section{Distribution}

J. haematoloma has been reported from some of the southeastern states west to Texas and California, several central states, and from Mexico, the West Indies, southward to Central America and Colombia; also Hawaii. In Florida, it ranges over the peninsula, but seems to be scarce in the north, and strangely absent from "panhandle" Florida, as discerned from records in the Florida State Collection of Arthropods (FSCA). J. haematoloma has been taken during every month in Florida, with May being the peak month, primarily in central Florida, the region containing the majority of records. In southern Florida, there is a more even distribution throughout the year, with no distinct spring peak according to FSCA records. $J$. antica records are scarce; it has been collected only a few times in Monroe and Dade Counties, and once in Osceola (15-III-56 by H.A. Denmark). Records (FSCA) for J. antica in Florida are in March, April, June, August, and November.

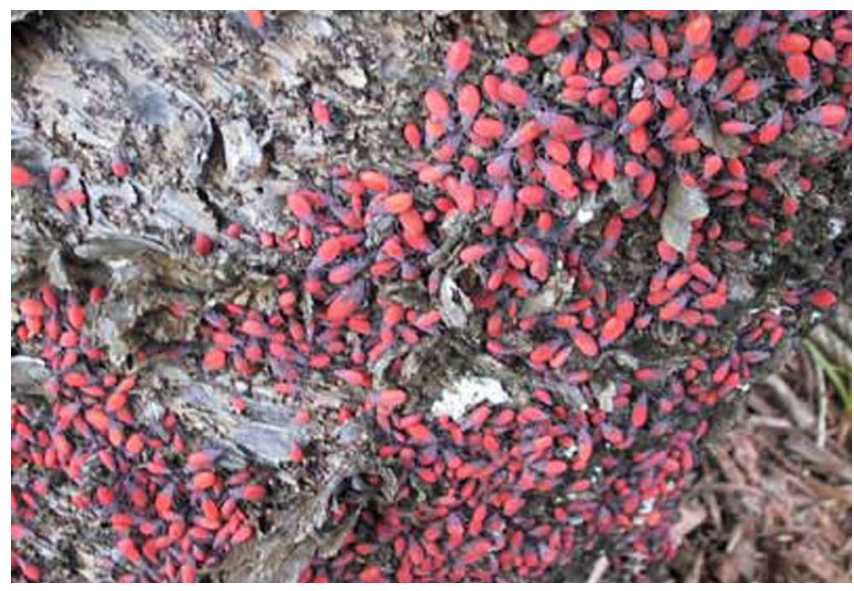

Figure 2. Nymphs of the Jadera bug, Jadera haematoloma (Herrich-Schaeffer), on a tree trunk in central Florida. Credits: Ronald Sperry

\section{Descriptions}

\section{Adults}

J. haematoloma (with normal wings) has a length of 9.5-13.5 $\mathrm{mm}$ and width of 3-4 $\mathrm{mm}$. The length of the shortwinged form (brachyptera) usually is 7-8 mm long. Adult color of J. haematoloma is mostly black or brownish-black except for reddish eyes and their orbits, ocelli, shoulders, and border area of abdomen. J. antica has a length 7.5-11 mm and a width $2.5-4.0 \mathrm{~mm}$. The color for J. antica is basically brownish-salmon, with some specimens more brownish, others more reddish; fuscous dots abundant over upper surface and on sides of the thorax; eyes, sides of head and shoulders. The is abdomen reddish and sprinkled with darker red spots. For more detailed technical descriptions or keys, consult Blatchley (1926), Gollner-Scheiding (1979), or Hoebeke and Wheeler (1982). For a broader understanding of Jadera and its relatives, consult Chopra (1967) and Schaefer and Chopra (1982).

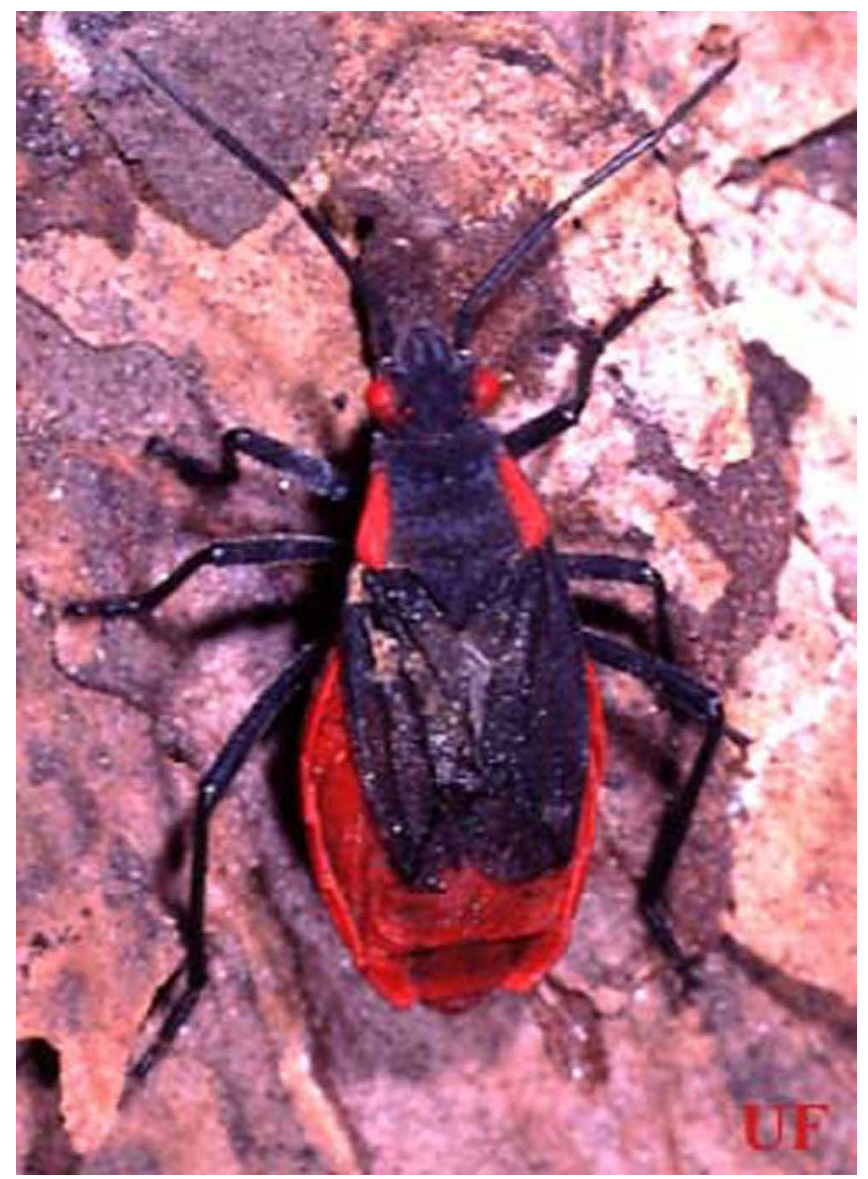

Figure 3. Adult Jadera bug, Jadera haematoloma (Herrich-Schaeffer). Credits: Paul M. Choate, University of Florida

\section{Nymphs}

The nymphs of both species are predominately reddish in color, with the thorax, antennae, beak, and legs brown. Small dark setae are nearly uniformly spaced over the whole body as revealed by a hand lens or microscope. The nymphs have the family 
characteristic of two abdominal scent glands lying so close together in the middle of the dorsal abdomen, that segment 5 is constricted at midline.

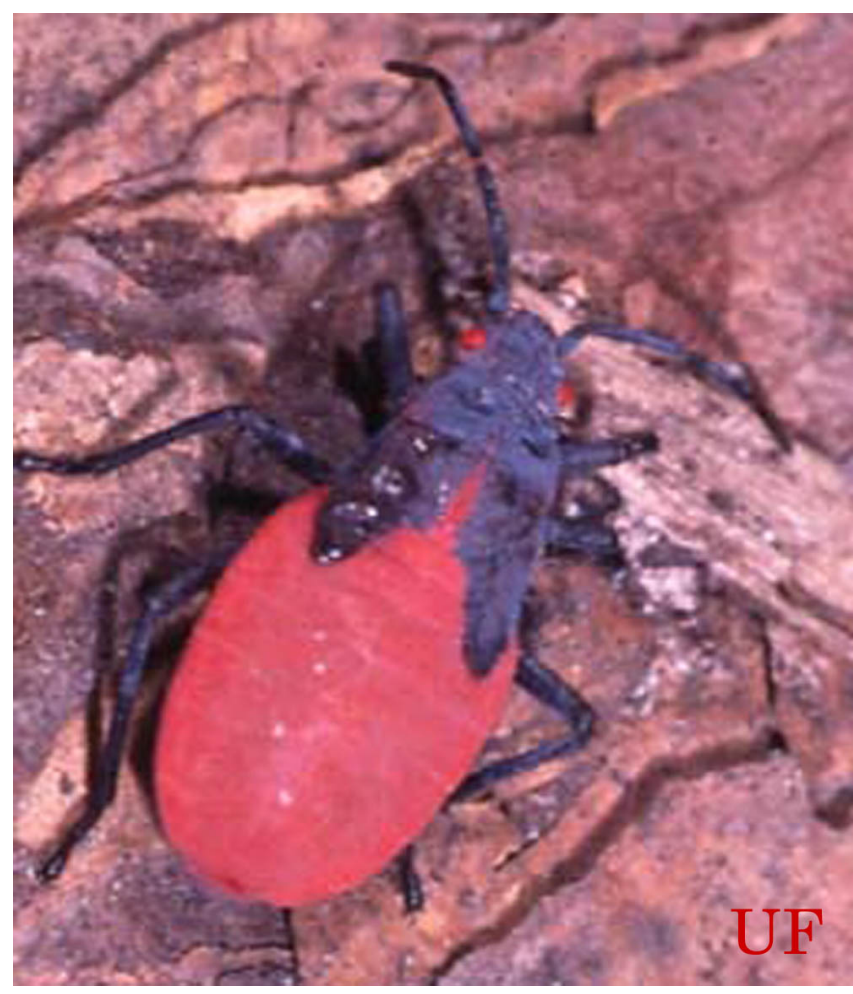

Figure 4. Nymph of the Jadera bug, Jadera haematoloma (Herrich-Schaeffer). Credits: Paul M. Choate, University of Florida

\section{Hosts}

Schaefer and Chopra (1982) reported that Jadera and the closely related genus Leptocoris of the subfamily Serinethinae have a clear preference for plants of the Sapindales, especially of the Sapindaceae. J. haematoloma feeds on a variety of plants but prefers balloonvine, Cardiospermum spp. (Sapindaceae) which grows in southern Florida. Additional hosts include other Sapindaceae, Ficus spp. (Moraceae) and Althaea spp. (Malvaceae). In some areas the bugs are observed feeding so often on goldenrain tree seeds, Koelreuteria spp., (Sapindaceae), that they are referred to as "goldenrain tree bugs."

\section{Survey and Detection}

Examine ground areas under trees shedding seeds, particularly goldenrain trees, where bugs come to feed on the seeds. Look for the dark, red-shouldered $1 / 2$ inch long adults primarily on leaves, stems, and ground areas. Nymphs are mostly a conspicuous red color.

\section{Management}

In most instances, no attempts to control Jadera spp. are necessary. Documentation is lacking as far as this being a plant pest of any consequence. A small concentration on a plant often can be destroyed by hand collecting. If the bugs are a nuisance in lawns or playgrounds, raking to remove the seeds that the bugs are feeding on should be helpful. If nonpesticidal methods are not practical, consult your local office of the Cooperative Extension Service for insecticide recommendations.

\section{Selected References}

Blatchley, W.S. 1926. Heteroptera or true bugs of eastern North America with especial reference to the faunas of Indiana and Florida. Nature Pub. Co., Indianapolis, IN. 1116 p.

Chopra, N.P. 1967. The higher classification of the family Rhopalidae (Hemiptera). Trans. Royal Entomol. Soc. London 119: 363-399.

Gollner-Scheiding, U. 1979. Die Gattung Jadera Stal, 1862 (Heteroptera, Rhopalidae). Deutsche Entomologische Zeitschrift 26: 47-75.

Hoebeke, E.R., and A.G.Wheeler, Jr. 1982. Rhopalus (Brachycarenus) tigrinus, recently established in North America, with a key to the genera and species of Rhopalidae in eastern North America (Hemiptera: Heteroptera). Proc. Entomol. Soc. Washington 85: 213-224.

Hamman, P.J.. (January 1997). Boxelder bugs. http://entowww.tamu.edu/extension/bulletins/l1830.html (22 May 2000).

Schaefer, C.W., and N.P. Chopra. 1982. Cladistic analysis of the Rhopalidae, with a list of food plants. Ann. Entomol. Soc. Amer. 75: 224-233.

Wheeler, A.G., Jr. 1990. Bed bugs and other bugs. Pp. 313-345 in A. Mallis, ed., Handbook of pest control: The behavior, life history, and control of household pests, 7th edit. Franzak \& Foster Co., Cleveland, $\mathrm{OH}$. 